\title{
Effect of foliar application of Boron and Magnesium on growth and yield of green chilli (Capsicum annum L.)
}

\author{
K. D. Harris ${ }^{1 *}$, T. Vanajah ${ }^{1}$ and S. Puvanitha ${ }^{2}$ \\ ${ }^{1}$ Department of Crop Science, Faculty of Agriculture, Eastern University, Chenkalady, Sri Lanka \\ 2Department of Agricultural Biology, Faculty of Agriculture, Eastern University, Chenkalady, \\ Sri Lanka.
}

\begin{abstract}
An experiment was conducted to study the effect of foliar application of boron (B) and magnesium $(\mathrm{Mg})$ on growth and yield of green chilli (Capsicum annum L.) cv. MIPC-1. Foliar application of Boron and Magnesium ( $\left.T_{0}\right)$ Control; $\left(T_{1}\right) B=50 \mathrm{ppm} ;\left(\mathrm{T}_{2}\right) B=100 \mathrm{ppm} ;\left(\mathrm{T}_{3}\right) B=150 \mathrm{ppm} ;\left(\mathrm{T}_{4}\right) \mathrm{Mg}=50 \mathrm{ppm} ;\left(\mathrm{T}_{5}\right)$ $M g=100 \mathrm{ppm} ;\left(\mathrm{T}_{6}\right) \mathrm{Mg}=150 \mathrm{ppm} ;\left(\mathrm{T}_{7}\right) \mathrm{B}(50 \mathrm{ppm})+\mathrm{Mg}(50 \mathrm{ppm}) ;\left(\mathrm{T}_{8}\right) B(100 \mathrm{ppm})+\mathrm{Mg}(100 \mathrm{ppm}) ;$ (T9) B (150 ppm) $+\mathrm{Mg}(150 \mathrm{ppm})$ was done. The sources of Boron and Magnesium were boric acid $\left(\mathrm{H}_{3} \mathrm{BO}_{3}\right)$ and Magnesium Sulphate $\left(\mathrm{MgSO}_{4} .7 \mathrm{H}_{2} \mathrm{O}\right)$. The treatments were laid out in a Completely Randomized Design (CRD) and replicated four times. All the agronomic practices were carried out in accordance with Department of Agriculture, Sri Lanka. Maximum plant height $(98 \mathrm{~cm})$, number of branches (18 plant $\left.t^{-1}\right)$, number of leaves (25 plant $\left.{ }^{-1}\right)$, number of flowers (29 plant $\left.{ }^{-1}\right)$, total dry weight (66 plant $\left.{ }^{-1}\right)$, number of fruits (24 plant $\left.{ }^{-1}\right)$, and unripe fruit yield (333 plant $\left.{ }^{-1}\right)$ were observed with the foliar application of Boron $\left(\mathrm{H}_{3} \mathrm{BO}_{3}\right)+$ Magnesium $\left(\mathrm{MgSO}_{4} .7 \mathrm{H}_{2} \mathrm{O}\right)$ at $100 \mathrm{ppm}$ and minimum was found in the control treatment. Foliar application of Boron $\left(\mathrm{H}_{3} \mathrm{BO}_{3}\right)+$ Magnesium $\left(\mathrm{MgSO}_{4} .7 \mathrm{H}_{2} \mathrm{O}\right)$ at $100 \mathrm{ppm}$ increased yield by three-fold than that of control treatment. Therefore, it is concluded that combined application of $B+M g$ at 100 ppm was found to be effective in enhancing plant growth and fruit yield of chilli.
\end{abstract}

Keywords: Boron, Chilli, Foliar application, Magnesium.

\section{Introduction}

Hot pepper (Capsicum annum L.), is commonly referred to as chilli. It is one of the most important Solanaceae spice crops cultivated across the world. It is considered to be important for its pungency, colour, and aroma as well as its high phytochemical content (Asnin and Park, 2013). Sixteen elements are known to be vital for the growth and development (Silva and Uchida, 2000) and inadequate supply of these nutrients leads to a reduction in yield. Therefore, plants should be fed with the nutrients continuously in order to get a higher yield. Nutrients are provided to the plants through both soil and foliar. Foliar application is the quickest and an excellent method of supplying plant nutrients. However, it needs repeated sprays, can be washed off by rains and for which the

Corresponding author: kumuthiniharris@yahoo.com Received: 14.03.2018 plants should have sufficient leaf area and higher concentration might cause leaf damage (Fageria et al., 2009). Boron (B) is taken up by plant roots as the neutral molecule $\mathrm{H}_{3} \mathrm{~B}_{3}$. B is important for both flower development and initial fruit or seed set (Borghi and Fernie, 2017) and maintaining the structural integrity of cell wall and cell membranes (Zhang et al., 2014). It enhances the percentage of fruit-set by promoting pollen germination and elongation of pollen tube (Abdalla, 2007). The first signs B deficiency is the decrease in seed or fruit set. The first signs B deficiency is the decrease in seed or fruit set. Magnesium is the central element in chlorophyll molecule. It is the livewire behind photosynthesis in plants. Without magnesium, chlorophyll cannot capture 
sun energy needed for photosynthesis and an integral part in partitioning and utilization of photo-assimilates, photophosphorylation (including ATP formation in chloroplasts) and loading of sucrose in the phloem, photo-oxidation in leaf tissues and the generation of reactive oxygen species (Cakmak and Yazici, 2010 and Kawamura and Rao, 2007). Hence, boron and magnesium nutrient can be provided through foliar application. Considering the significance of foliar nutrients, this investigation was carried out to study the effect of foliar application of boron and magnesium on growth and yield of green chilli.

\section{Materials and Methods}

The experiment was carried out at the Crop Farm, Eastern University, Sri Lanka during the period September 2016 to November 2016 to study the effect of foliar application of boron and magnesium on growth and the yield of chilli (Capsicum annuum L.) cv MIPC -1 . Seedlings were sown on a nursery bed in $4^{\text {th }}$ August 2016 and transplanted on $4^{\text {th }}$ September 2016 into poly bags containing a mixture of red soil, sand and rotted cattle manure in the proportion of 1:1:1. The treatments were laid out in a Completely Randomized Design (CRD) and replicated four times. Different concentrations of Boron and Magnesium were applied as foliar sprays. The experiment comprised of following treatments: $\left(\mathrm{T}_{0}\right)$ Control; $\left(\mathrm{T}_{1}\right) \mathrm{B}=$ 50 ppm; $\left(\mathrm{T}_{2}\right) \mathrm{B}=100 \mathrm{ppm}$; $\left(\mathrm{T}_{3}\right) \mathrm{B}=150 \mathrm{ppm}$; $\left(\mathrm{T}_{4}\right) \mathrm{Mg}=50 \mathrm{ppm} ;\left(\mathrm{T}_{5}\right) \mathrm{Mg}=100 \mathrm{ppm} ;\left(\mathrm{T}_{6}\right)$ $\mathrm{Mg}=150 \mathrm{ppm} ;\left(\mathrm{T}_{7}\right) \mathrm{B}(50 \mathrm{ppm})+\mathrm{Mg}(50$ ppm); ( $\left.\mathrm{T}_{8}\right) \mathrm{B}(100 \mathrm{ppm})+\mathrm{Mg}$ (100 ppm); ( $\left.\mathrm{T}_{9}\right)$ B $(150 \mathrm{ppm})+\mathrm{Mg}(150 \mathrm{ppm})$. The first application was done at flower bud initiation stage and second spray at 14 days after the first spray. The sources of Boron and Magnesium were boric acid $\left(\mathrm{H}_{3} \mathrm{BO}_{3}\right)$ and Magnesium Sulphate $\left(\mathrm{MgSO}_{4} \cdot 7 \mathrm{H}_{2} \mathrm{O}\right)$. Foliar applications were done at early morning for better absorption of nutrients. All the agronomic practices were carried out in accordance with the recommendation made by the Department of Agriculture, Sri Lanka. The parameters viz. plant height, number of leaves per plant, number of flowers per plant, total biomass (total fresh weight of plant) and fresh weight of pods at harvest were measured. Fresh weight of pods (green chilli) was recorded from six (6) picks. Data were statistically analysed using SAS 9.1 and means were separated using Duncan's Multiple Range Test (DMRT) test at $5 \%$ significant level.

\section{Results and Discussion}

\section{Plant height}

Plant height was significantly different at different stages of growth (Table 1). At 2 weeks after transplanting (WAT) the highest plant height was obtained at $\mathrm{T}_{8}$ and $T_{9}$ followed by $T_{6}$ and then by $T_{2}$ and $T_{3}$, respectively and the lowest plant height was obtained at $\mathrm{T}_{0}$. At $5 \mathrm{WAT}$, maximum plant height was recorded in $\mathrm{T}_{8}$ followed by $\mathrm{T}_{9}$ and $\mathrm{T}_{6}$, respectively. At $7 \mathrm{WAT}$, highest plant height was attained in $\mathrm{T}_{8}$ followed by $\mathrm{T}_{9}$ and the $\mathrm{T}_{6}$. In all stages, plant height was the highest at $\mathrm{T}_{8}$ and lowest was with the control treatment $\left(T_{0}\right)$. This was mainly due to the contribution of the combined effect of Boron and Magnesium at the rate of 100 ppm.

Similar findings of increase in plant height due to the application of boron was also reported by Fakir et al. (2016) in wheat; Halder et al. (2007) in ginger ( $3 \mathrm{~kg} / \mathrm{ha})$; Haleema et al. (2018) (0.25\%) in tomato; Verma et al. (1973) in tomato; Singh and Singh (1974) in garlic and Basavarajeswari et al. (2008) in tomato. It was also observed that foliar application of Boron at the rate of $75 \mathrm{ppm}$ increased plant height in pepper (Shnain et al., 2014). Foliar application of 5.0 g L-1 (5000 ppm) Magnesium Sulphate significantly increased plant height in wheat (El-Nour et al., 2012). This might be due to the contribution of magnesium which is responsible for photosynthesis, act as a carrier of phosphorus, enhancement of nutrient uptake, synthesis of sugar and translocation of starch. Therefore, by combining both Boron and Magnesium together, the effect is double or more. 
Table 1. Effect of foliar application of B and Mg on mean plant height

\begin{tabular}{|c|c|c|c|}
\hline \multirow{2}{*}{ Treatment } & \multicolumn{3}{|c|}{ Weeks After Transplanting (WAT) } \\
\hline & $2 \mathrm{WAP}$ & $5 \mathrm{WAP}$ & $7 \mathrm{WAP}$ \\
\hline $\mathrm{T}_{0}$ : Control & $27.02 \pm 0.15^{f}$ & $42.00 \pm 0.11 \mathrm{~g}$ & $51.00 \pm 0.15 j$ \\
\hline $\mathrm{T}_{1}: \mathrm{B}-50 \mathrm{ppm}$ & $29.03 \pm 0.11^{e}$ & $56.00 \pm 0.12^{\mathrm{ef}}$ & $70.00 \pm 0.02^{\mathrm{i}}$ \\
\hline $\mathrm{T}_{2}: \mathrm{B}-100 \mathrm{ppm}$ & $32.53 \pm 0.03 c$ & $63.00 \pm 0.64^{c}$ & $81.00 \pm 0.29 \mathrm{~g}$ \\
\hline $\mathrm{T}_{3}: \mathrm{B}-150 \mathrm{ppm}$ & $33.03 \pm 0.43 c$ & $70.00 \pm 0.23^{b}$ & $86.00 \pm 0.25^{\mathrm{d}}$ \\
\hline $\mathrm{T}_{4}: \mathrm{Mg}-50 \mathrm{ppm}$ & $30.53 \pm 0.37 \mathrm{~d}$ & $55.00 \pm 0.15^{f}$ & $80.00 \pm 0.24^{h}$ \\
\hline $\mathrm{T}_{5}: \mathrm{Mg}-100 \mathrm{ppm}$ & $31.03 \pm 0.37 \mathrm{~d}$ & $60.00 \pm 0.59 \mathrm{~d}$ & $84.00 \pm 0.39 \mathrm{f}$ \\
\hline $\mathrm{T}_{6}: \mathrm{Mg}-150 \mathrm{ppm}$ & $34.02 \pm 0.25^{b}$ & $69.00 \pm 0.52^{b}$ & $87.00 \pm 0.38^{c}$ \\
\hline $\mathrm{T}_{7}: \mathrm{B}+\mathrm{Mg}-50 \mathrm{ppm}$ & $31.03 \pm 0.23 \mathrm{~d}$ & $57.00 \pm 1.11 \mathrm{e}$ & $85.00 \pm 0.41 \mathrm{e}$ \\
\hline $\mathrm{T}_{8}: \mathrm{B}+\mathrm{Mg}-100 \mathrm{ppm}$ & $36.50 \pm 0.31^{a}$ & $73.00 \pm 0.07 a$ & $98.00 \pm 0.23^{a}$ \\
\hline $\mathrm{T}_{9}: \mathrm{B}+\mathrm{Mg}-150 \mathrm{ppm}$ & $37.00 \pm 0.57 \mathrm{a}$ & $70.00 \pm 0.05^{b}$ & $91.00 \pm 0.19 \mathrm{~b}$ \\
\hline F Test & ** & ** & ** \\
\hline
\end{tabular}

* Means followed by the same letter in each column are not significantly different to DMRT at $5 \%$ level.

* Values are the means of 10 plants in 4 replications.

\section{Number of branches}

Boron and Magnesium had a significant influence on the number of branches plant $^{-1}$ of chilli. Maximum number of branches plant ${ }^{-1}$ was recorded in treatment $\mathrm{T}_{9}(\mathrm{~B}+\mathrm{Mg}-150 \mathrm{ppm})(18),(\mathrm{B}+\mathrm{Mg}-100$ ppm, $\mathrm{T}_{8}(\mathrm{~B}+\mathrm{Mg}-150 \mathrm{ppm})(17)$, and $\mathrm{T}_{6}$ (Mg - $150 \mathrm{ppm})$ (17) and significantly higher than the other treatments tested. However, the minimum number of branches plant $^{-1}$ (10) was recorded in control plots, where no foliar nutrients were applied. This is in concurrence with the studies of Sharma et al. (2000) who reported that compound liquid fertilizer containing most macro and micro nutrients "Polyfeed and Multi" along with NPK had significantly increased the number of branches plant ${ }^{-1}$. Application of boron had a marked effect on the number of branches was reported by Basavarajeswari et al. (2008) in tomato; Saha et al. (2010) in broccoli and Saptari and Dewi (2013) in chilli. Waskela et al. (2013) reported that the foliar application of Magnesium sulphate at $0.75 \%$ (7500 ppm) significantly increased the number of branches in guava. While Venkatramana (2012) documented that application of $40 \mathrm{~g} \mathrm{MgSO}_{4}+4 \mathrm{~g}$ Borax had a remarkable influence on the number of branches.

\section{Number of leaves}

The number of leaves plant ${ }^{-1}$ was significantly affected by the foliar application of $\mathrm{B}$ and $\mathrm{Mg}$ (Table 02). The maximum number of leaves plant ${ }^{-1}(27,25$ and 25) was observed in $\mathrm{T}_{9}$ (Boron and Magnesium at $150 \mathrm{ppm}$ ), $\mathrm{T}_{8}$ (Boron and Magnesium at $100 \mathrm{ppm}$ ), ) and $\mathrm{T}_{6}$ (sole application of $\mathrm{MgSO}_{4}$ at $150 \mathrm{ppm}$ ), respectively. While treatment $\mathrm{T}_{3}$ (sole application of Boron at 150 ppm (24) and 
100 ppm (22) produced a higher number of leaves plant ${ }^{-1}$ than $\mathrm{T}_{0}$ (Control). Control gave the minimum number of leaves plant $^{-1}$ (15). Foliar application of B at the rate of $75 \mathrm{ppm}$ increased the number of leaves was reported by El-Mahdy (2007) in pepper and Harris and Puvanitha (2017) in tomato. While Waskela et al. (2013) reported that foliar application of Magnesium sulphate at $0.75 \%$ (7500 ppm) significantly increased the leaves per shoot. Venkataramana (2012) documented that application of $40 \mathrm{~g} \mathrm{MgSO}_{4}$ and $4 \mathrm{~g}$ Borax increased the number of leaves in pepper vine. These results were obtained partly due to the effect of $\mathrm{Mg}$ which involved in the synthesis of chlorophyll (Ibrahim, 2010) and activation of enzymes (Calvin cycle) and phosphoenol pyruvate carboxylase (C $\mathrm{C}_{3}$-plants pathway of $\mathrm{CO}_{2}$ fixation) (Bidwell, 1979).

Table 2. Effect of foliar application of $\mathrm{B}$ and $\mathrm{Mg}$ on mean number of branches and leaves

\begin{tabular}{|c|c|c|}
\hline Treatment & Number of Branches plant ${ }^{-1}$ & Number of Leaves \\
\hline $\mathrm{T}_{0}:$ Control & $10 \pm 0.577 \mathrm{e}$ & $15 \pm 0.58^{\mathrm{f}}$ \\
\hline $\mathrm{T}_{1}: \mathrm{B}-50 \mathrm{ppm}$ & $13 \pm 0.577 \mathrm{~d}$ & $18 \pm 0.88 \mathrm{e}$ \\
\hline $\mathrm{T}_{2}: \mathrm{B}-100 \mathrm{ppm}$ & $15 \pm 0.577^{c}$ & $22 \pm 1.20^{\mathrm{cd}}$ \\
\hline $\mathrm{T}_{3}: \mathrm{B}-150 \mathrm{ppm}$ & $16 \pm 0.001^{b c}$ & $21 \pm 0.66^{\mathrm{cd}}$ \\
\hline $\mathrm{T}_{4}: \mathrm{Mg}-50 \mathrm{ppm}$ & $15 \pm 0.577 \mathrm{c}$ & $20 \pm 1.15^{\mathrm{de}}$ \\
\hline $\mathrm{T}_{5}: \mathrm{Mg}-100 \mathrm{ppm}$ & $16 \pm 0.577 \mathrm{bc}$ & $23 \pm 0.58 \mathrm{bc}$ \\
\hline $\mathrm{T}_{6}: \mathrm{Mg}-150 \mathrm{ppm}$ & $17 \pm 0.577 \mathrm{ab}$ & $25 \pm 0.33 \mathrm{ab}$ \\
\hline $\mathrm{T}_{7}: \mathrm{B}+\mathrm{Mg}-50 \mathrm{ppm}$ & $15 \pm 0.577 \mathrm{c}$ & $19.67 \pm 0.88 \mathrm{de}$ \\
\hline $\mathrm{T}_{8}: \mathrm{B}+\mathrm{Mg}-100 \mathrm{ppm}$ & $18 \pm 0.001^{\mathrm{a}}$ & $25 \pm 1.20 b^{a}$ \\
\hline $\mathrm{T}_{9}: \mathrm{B}+\mathrm{Mg}-150 \mathrm{ppm}$ & $17 \pm 0.577 \mathrm{ab}$ & $27 \pm 0.88^{a}$ \\
\hline F Test & $* *$ & ** \\
\hline
\end{tabular}

* Means followed by the same letter in each column are not significantly different to DMRT at $5 \%$ level.

* Values are the means of 10 plants in 4 replications.

\section{Numbers of flowers}

The result pertaining to the effect of boron and magnesium on the number of flowers plant ${ }^{-1}$ is given in Table 3. At 5 and 7 WAT there was a significant difference between treatments with respect to the foliar application of boron and magnesium. At 5 and 7 WAT, the number of flower plant ${ }^{-1}$ ranged from $8-28$. At 5 and 7 WAT, the highest number of flowers plant ${ }^{-1}$ was observed in $\mathrm{T}_{8}$ and $\mathrm{T}_{9}$. At 7 WAT maximum number of flowers per plant ${ }^{-1}$ (29 and 28) was observed in plants receiving boron and magnesium at the rate of 100 and 150 ppm, respectively which were significantly higher than $\mathrm{T}_{6}(26), \mathrm{T}_{7}(25)$ and $\mathrm{T}_{3}(24)$, while minimum number of flowers plant ${ }^{-1}$ (12) were noticed in control treatment $\left(\mathrm{T}_{0}\right)$. The higher number of flowers plant ${ }^{-1}$ might be due to the adequate supply of $\mathrm{B}$ and $\mathrm{Mg}$ which results in increased plant height and the production branches that in turn increases the number of nodes and then the number of flowers. 
Table 3. Effect of foliar application of $\mathrm{B}$ and $\mathrm{Mg}$ on average number of Flowers

\begin{tabular}{|l|c|c|}
\hline \multirow{2}{*}{ Treatment } & \multicolumn{2}{c|}{ Weeks After Transplanting (WAT) } \\
\cline { 2 - 3 } & $\mathbf{5 ~ W A P}$ & $\mathbf{5}$ WAP \\
\hline $\mathrm{T}_{0}:$ Control & $8 \pm 0.58^{\mathrm{g}}$ & $12 \pm 0.58^{\mathrm{g}}$ \\
\hline $\mathrm{T}_{1}: \mathrm{B}-50 \mathrm{ppm}$ & $12 \pm 0.58^{\mathrm{f}}$ & $18 \pm 0.58^{\mathrm{f}}$ \\
\hline $\mathrm{T}_{2}: \mathrm{B}-100 \mathrm{ppm}$ & $17 \pm 0.58 \mathrm{dc}^{\mathrm{c}}$ & $22 \pm 1.00^{\mathrm{de}}$ \\
\hline $\mathrm{T}_{3}: \mathrm{B}-150 \mathrm{ppm}$ & $15 \pm 0.58^{\mathrm{de}}$ & $24 \pm 1.15^{\mathrm{cd}}$ \\
\hline $\mathrm{T}_{4}: \mathrm{Mg}-50 \mathrm{ppm}$ & $14 \pm 0.01^{\mathrm{ef}}$ & $20 \pm 1.15^{\mathrm{ef}}$ \\
\hline $\mathrm{T}_{5}: \mathrm{Mg}-100 \mathrm{ppm}$ & $18 \pm 1.15^{\mathrm{bc}}$ & $27 \pm 0.58^{\mathrm{abc}}$ \\
\hline $\mathrm{T}_{6}: \mathrm{Mg}-150 \mathrm{ppm}$ & $17 \pm 1.00^{\mathrm{cd}}$ & $26 \pm 1.15^{\mathrm{bc}}$ \\
\hline $\mathrm{T}_{7}: \mathrm{B}+\mathrm{Mg}-50 \mathrm{ppm}$ & $16 \pm 1.00 \mathrm{dcde}^{\mathrm{cde}}$ & $25 \pm 1.00^{\mathrm{bcd}}$ \\
\hline $\mathrm{T}_{8}: \mathrm{B}+\mathrm{Mg}-100 \mathrm{ppm}$ & $21.33 \pm 0.33^{\mathrm{a}}$ & $29.33 \pm 0.88^{\mathrm{a}}$ \\
\hline $\mathrm{T}_{9}: \mathrm{B}+\mathrm{Mg}-150 \mathrm{ppm}$ & $20 \pm 0.58^{\mathrm{ab}}$ & $28 \pm 1.53^{\mathrm{ab}}$ \\
\hline $\mathrm{F} \mathrm{Test}$ & $* *$ & ${ }^{* *}$ \\
\hline
\end{tabular}

* Means followed by the same letter in each column are not significantly different to DMRT at $5 \%$ level.

* Values are the means of 10 plants in 4 replications.

\section{Yield and yield components}

\section{Number of fruits}

The foliar application of Boron and Magnesium significantly increased the number of fruits plant ${ }^{-1}$ (Table 4 ). The chilli crop that was supplied with combined application of $\mathrm{B}$ and $\mathrm{Mg}$ at the rate of 100 (24 fruits) and $150 \mathrm{ppm}$ (22 fruits) produced maximum number of fruits plant $^{-1}$ followed by combined application of B and $\mathrm{Mg}$ at the rate of 50 ppm (19 fruits) and $\mathrm{Mg}$ at the rate of $50 \mathrm{ppm} 100 \mathrm{ppm}$ (18 fruits). However, a minimum number of fruits plant $^{-1}$ was recorded in the control plants (7) (Table 4). It was observed that as the number of branches plant ${ }^{-1}$ increased, the number of fruits plant ${ }^{-1}$ also increased. From this result, it is apparent that the B and $\mathrm{Mg}$ played an important role in increasing the number of fruits in chilli plants. The increase in the number of fruits might be due to the contribution of Boric acid and $\mathrm{MgSO}_{4}$.

\section{Fresh weight of fruits}

Foliar application of B and $\mathrm{Mg}$ significantly influenced the fresh weight of fruits plant ${ }^{-1}$ (Table 4). The fresh weight of fruits plant ${ }^{-1}$ was remarkably highest (333g) in plants receiving the foliar application of boron and magnesium at $100 \mathrm{ppm}$ followed by fresh weight of $306 \mathrm{~g}$ at the combined foliar application of $\mathrm{H}_{3} \mathrm{BO}_{3}$ and $\mathrm{MgSO}_{4}$ at 150 ppm and then with the plants receiving boron alone at $150 \mathrm{ppm}$ (Table 4). The control gave the lowest fresh weight of fruits. In this study, foliar application of B and $\mathrm{Mg}$ at 100 ppm increased yield by three-fold than that of control treatment (Table 4). Adequate quantity of micronutrients at the correct time is needed for greater growth which in turn leads to higher yield. Therefore, the higher yield was due to the effect of better flowering and higher fruit-set (Ram and Bose, 2000). Similar results have been reported by Budadeb (2012) and Uddin et al. (2008) in wheat; Khan et al. (2006) in paddy. Babaeian et al. (2012) showed that contribution of $\mathrm{Mg}$ in the yield of Barley. Venkatramana (2012) reported that foliar 
application of $1 \% \mathrm{MgSO}_{4}$ and $0.5 \%$ Borax increased the yield in pepper. This was due to the fact that boron was needed for vegetative growth and it had a great contribution in increasing the flower production and retention, elongation of pollen tube and germination and seed and fruit setting and development (Oosterhuis, 2001). Bhatia et al. (2001) recorded the highest yield of guava with the sole application of $1 \% \mathrm{H}_{3} \mathrm{BO}_{3}$ (equivalent to $10,000 \mathrm{ppm}$ ) which are ten times (10) higher the concentration used in this experiment and it also due to the contribution of $\mathrm{MgSO}_{4}$ too. However, Khayyat et al. (2007) recorded that the highest yield was obtained with the foliar spray of $\mathrm{H}_{3} \mathrm{BO}_{3}(1500 \mathrm{ppm})$ which is fifteen times (15) greater than the concentration used in this experiment.

Table 4. Effect of foliar application of $\mathrm{B}$ and $\mathrm{Mg}$ on average number and weight of fruits at harvest

\begin{tabular}{|c|c|c|}
\hline Treatment & Number of fruits & Fresh weight of fruits (g) \\
\hline $\mathrm{T}_{0}$ : Control & $7.0 \pm 0.12 \mathrm{~g}$ & $139.0 \pm 1.00^{\mathrm{i}}$ \\
\hline $\mathrm{T}_{1}: \mathrm{B}-50 \mathrm{ppm}$ & $14.0 \pm 0.56^{f}$ & $214.0 \pm 1.15^{\mathrm{h}}$ \\
\hline $\mathrm{T}_{2}: \mathrm{B}-100 \mathrm{ppm}$ & $16.0 \pm 1.01^{\text {ef }}$ & $266.0 \pm 1.15^{\mathrm{e}}$ \\
\hline $\mathrm{T}_{3}: \mathrm{B}-150 \mathrm{ppm}$ & $19.0 \pm 1.15^{\mathrm{cd}}$ & $278.0 \pm 1.73^{c}$ \\
\hline $\mathrm{T}_{4}: \mathrm{Mg}-50 \mathrm{ppm}$ & $17.0 \pm 0.57 \mathrm{de}$ & $226.0 \pm 1.15 \mathrm{~g}$ \\
\hline $\mathrm{T}_{5}: \mathrm{Mg}-100 \mathrm{ppm}$ & $18.3 \pm 1.2^{\text {cde }}$ & $260.0 \pm 1.15^{\mathrm{f}}$ \\
\hline $\mathrm{T}_{6}: \mathrm{Mg}-150 \mathrm{ppm}$ & $21.0 \pm 1.15^{\mathrm{bc}}$ & $274.0 \pm 1.15^{\mathrm{d}}$ \\
\hline $\mathrm{T}_{7}: \mathrm{B}+\mathrm{Mg}-50 \mathrm{ppm}$ & $19.0 \pm 1.73^{\mathrm{cd}}$ & $256.3 \pm 1.45^{\mathrm{f}}$ \\
\hline $\mathrm{T}_{8}: \mathrm{B}+\mathrm{Mg}-100 \mathrm{ppm}$ & $24.0 \pm 1.73^{a}$ & $333.0 \pm 1.73^{a}$ \\
\hline $\mathrm{T}_{9}: \mathrm{B}+\mathrm{Mg}-150 \mathrm{ppm}$ & $22.0 \pm 1.2^{\mathrm{ab}}$ & $306.0 \pm 1.15^{b}$ \\
\hline F Test & $* *$ & $* *$ \\
\hline
\end{tabular}

* Means followed by the same letter in each column are not significantly different to DMRT at $5 \%$ level.

* Values are the means of 10 plants in 4 replications.

\section{Conclusion}

Foliar application of boron (B) and magnesium $(\mathrm{Mg})$ had a significant effect on growth and fruit production of chilli. It revealed that combined application of $\mathrm{B}+$ $\mathrm{Mg}$ at the rate of $100 \mathrm{ppm}$ improved plant height, number of branches plant ${ }^{-1}$, number of leaves plant ${ }^{-1}$, the number of flowers plant ${ }^{-1}$, total weight plant $^{-1}$, number of fruits plant ${ }^{-1}$ and fruit weight plant $^{-1}$. However, the combined application of $\mathrm{B}+\mathrm{Mg}$ at $150 \mathrm{ppm}$ had an equal effect on the number of leaves plant $^{-1}$, number of flowers plant ${ }^{-1}$ and number of fruits plant ${ }^{-1}$. Therefore, it is concluded that that combined application of $\mathrm{B}+\mathrm{Mg}$ at $100 \mathrm{ppm}$ was found to be effective in enhancing plant growth and fruit yield of green chilli.

\section{References}

Abdalla, M. M. and El-Khoshiban, N. H. (2007). The influence of water stress on growth, relative water content, photosynthetic pigments, some metabolic and hormonal contents of two Triticium aestivum cultivars. Journal of Applied Sciences Research, 3(12): 2062-2074.

Asnin, L. and Park, S. W. (2015). Isolation and analysis of bioactive compounds in capsicum peppers. Critical reviews in food science and nutrition, 55(2):254-289. 
Babaeian, M., Esmaeilian, Y., Tavassoli, A. and Asgharzade, A. (2012). Efficacy of different iron, zinc and magnesium fertilizers on yield and yield components of barley. African Journal of Microbiology Research, 6(28): 5754-5756.

Basavarajeswari, C. P., Hosamni, R. M., Ajjappalavara, P. S., Naik, B. H. and Smitha, R. P. U. (2008). Effect of foliar application of micronutrients on growth, yield components of Tomato (Lycopersicon esculentum Mill). Karnataka Journal of Agricultural Sciences, 21(3): 428430.

Bhatia, M., Saluja, A.K., Singh, V.P., Frossard, J.L., Lee, H.S., Bhagat, L. (2001). American Journal of Physiology, 280:974978.

Bidwell, R. G. S. (1979). Plant Physiology. 2nd Edition. Published by Macmillan Publishing Co.

Borghi, M. and Fernie, A. R. (2017). Floral metabolism of sugars and amino acids: implications for pollinators' preferences and seed and fruitset. Plant physiology, 175(4): 1510-1524.

Borghi, M., Fernie, A. R., Schiestl, F. P. and Bouwmeester, H. J. (2017). The sexual advantage of looking, smelling, and tasting good: the metabolic network that produces signals for pollinators. Trends in plant science,22(4), 338-350.

Cakmak, I. and Yazici, A. M. (2010). Magnesium: A forgotten element in crop production. Better Crops, 94(2): 23-25.

El-Mahdy, R.E. (2007). Effect of heavy nitrogen application on pepper plant (Capsicum annuum). M. Sc. Thesis. Faculty of Agriculture. Mansoura University, Egypt.

El-Nour, E. Z. A. A. and Shaaban, M. M. (2012). Response of wheat plants to magnesium sulphate fertilization. American Journal of Plant Nutrition and Fertilization Technology, 2(2): 56-63.

Fageria, N. K., Filho, M. B., Moreira, A. and Guimarães, C. M. (2009). Foliar fertilization of crop plants. Journal of Plant Nutrition, 32(6):1044-1064.

Fakir, O. A., Rahman, M. A. and Jahiruddin, M. (2016). Effects of Foliar Application of Boron (B) on the Grain Set and Yield of Wheat (Triticum aestivum L.). American Journal of Experimental Agriculture, 12(2): 1-8.

Halder, N.K., Shill, N.C., Siddiky, M.A. Gomes, R. and Sarkar, J. (2007). Response of Ginger to Zinc and Boron Fertilization. Asian Journal of Plant Sciences, 6(2): 394-398.

Haleema, B., Rab, A. and Hussain, S. A. (2018). Effect of calcium, boron and zinc foliar application on growth and fruit production of tomato. Sarhad Journal of Agriculture, 34(1): 19-30.

Harris, K. D. and Puvanitha, S. (2018). Influence of Foliar Application of Boron and Copper on Growth and Yield of Tomato (Solanum lycopersicum L. cv 'Thilina'). AGRIEAST: Journal of Agricultural Sciences, 11(2):12-19.

Hawkesford, M. J., Kopriva, S. and De Kok, L. J. (2016). Nutrient Use Efficiency in Plants.: Concepts and Approaches. (C) Springer International Publishing Switzerland.

Hu, Q. H., Xu, G. B. and Shi, R. H. (1991). Study on the inheritable difference on $\mathrm{B}$ nutrition of different cultivars of oil seed rape (Brassica napus). Journal of Nanjing Agricultural University, 13(1): 80-86.

Kawamura, Y. and Rao, M. (2007). Magnesium Sulphate: Chemical and Technical Assessment.

Khan, R., Gurmani, A.H., Gurmani, A.R. and Zia, M.S. (2006). Effect of boron 
application on rice yield under wheat rice system. International Journal of Agriculture and Biology, 8(6): 805-808.

Khayyat, M., Tafazoli, E., Eshghi, S. and Rajaee, S. (2007). Effect of Nitrogen, Boron, Potassium and Zinc Sprays on Yield and Fruit Quality of Date Palm. AmericanEurasian Journal of Agricultural and Environmental Sciences, 2 (3): 289-296.

Marschner H. (1995). Mineral nutrition of higher plants. Second Edition. Pp.889. London: Academic Press.

Oosterhuis, D. (2001). Physiology and nutrition of high yielding cotton in the USA. Informações Agronômicas, 95: 18-24.

Ram, R.A. and Bose, T.K. (2000). Effect of foliar application of magnesium and micronutrients on growth, yield and fruit quality of mandarin orange (Citrus reticulata Blanco). Indian Journal of Horticulture, 57(3): 215-220.

Saha. P., Chatterjee, R. and Das, N.R. (2010). Effect of foliar application of boron and molybdenum in sprouting broccoli (Brassica oleracea Var. italica Plenck). Research Journal of Agricultural Sciences, 1(4): 335-337.

Saptari, R. T. and Dewi, K. (2013). Effect of borax and gibberellic acid on the growth and development of red chilli (Capsicum annuum L. "gelora"). The Third Basic Science International Conference. (B41) (pp. 1-3).

Sharma, K. R., Srivastava, P. C., Ghosh, D. and Agnihorti, A. K. (2000). Effect of different carbon sources and incubation temperatures on extractability of added boron in an Inceptions. Proceedings of the International Conference on Managing Natural Resources for Sustainable Agricultural Production in the 21st Century, 2: 280-282.
Shnain, R. S., Prasad, V.M. and Saravanan, S. (2014). Effect of zinc and boron on growth, yield and quality of tomato (Lycopersicon esculentum. Mill) cv. Heem Sohna, under protected cultivation. European Academic Research, 2 (3): 45724597.

Silva, J. A. and Uchida, R. S. (2000). Plant nutrient management in Hawaii's soils: Approaches for tropical and subtropical agriculture. University of Hawaii.

Singh, R.K. and Singh, K.P. 1974. Proceedings of Bihar academy of Agricultural Sciences, 25(2): 24-27.

Uddin, A., Gawlinski, K. and Stevens, M. (2008). Boron Nutrition on Yield and Yield Parameters of Wheat. Journal of Plant Nutrition, 9:1365-1378.

Venkataramana, P. (2012). Magnesium and boron nutrition of black pepper (Piper nigrum L.). In laterite soils. M. Sc. Thesis. Faculty of Agriculture, Kerala Agriculture University, India.

Verma, A. N., Ram, K., and Sharma, R. K. (1973). Growth yield and quality of tomato (Lycopersicon esculentum Mill) as affected by foliar applications of boron in sand culture. Mysore Journal of Agricultural Sciences, 7: 130-132.

Waskela, R. S., Kanpure, R. N., Kumawat, B. R. and Kachouli, B. K. (2013). Effect of foliar spray of micronutrients on growth, yield and quality of Guava (Psidium guajava L.) cv. DharidarInternational Journal of Research in Agricultural Sciences, 9(2): 551556.

Zhang, D., Zhao, H., Shi, L. and Xu, F. (2014). Physiological and genetic responses to boron deficiency in Brassica napus: A review. Soil science and plant nutrition, 60(3): 304-313. 